\title{
PRZELEW TRAPEZOWY O PIONOWEJ ŚCIANIE WLOTOWEJ
}

\author{
Sławomir Bajkowski ${ }^{\bowtie}$
}

Wydział Budownictwa i Inżynierii Środowiska, Szkoła Główna Gospodarstwa Wiejskiego w Warszawie, Warszawa

\begin{abstract}
STRESZCZENIE
W artykule opisano wykorzystanie badań laboratoryjnych oraz nowoczesnych technik obliczeniowych do wyznaczenia układu swobodnego zwierciadła wody nad przelewem o szerokiej koronie. Analizy przeprowadzono dla jazu trapezowego o pionowej ścianie górnej i ścianie dolnej nachylonej w stosunku 1:1. Fizyczne badania modelowe wykonano w kanale laboratoryjnym szerokości 0,20 m i długości 4,0 m. Symulacje komputerowe przeprowadzono metodą VOF stosowaną w technikach obliczeń mechaniki płynów CFD z wykorzystaniem środowiska programistycznego ANSYS-Fluent. Współrzędne zwierciadła wody uzyskane z symulacji numerycznych są zbliżone do wartości pomierzonych. Potwierdzają to analizy statystyczne, które wykazały znakomitą zgodność korelacyjną współrzędnych obliczonych z pomierzonymi.
\end{abstract}

Słowa kluczowe: przelew o szerokiej koronie, swobodne zwierciadło wody, badania laboratoryjne, obliczenia numeryczne

\section{WSTĘP}

Przelewy stałe o zróżnicowanych kształtach przekroju progu należą do konstrukcji najczęściej stosowanych jako urządzenia pomiarowe oraz elementy przelewowe budowli wodnych. Natężenie przepływu przelewów oblicza się, wykorzystując teoretyczne formuły, do których wprowadzane są empiryczne współczynniki wydatku ustalane z badań laboratoryjnych lub terenowych. Wyniki testów laboratoryjnych i pomiarów terenowych stosuje się również do określenia form przepływu strumienia na szerokości korony przelewu. Badania terenowe wydatku oraz układu zwierciadła wody są trudne do przeprowadzenia, szczególnie na obiektach dużych. Przelewy laboratoryjne montowane są w systemach zasilających stanowiska badawcze, na których prowadzone są badania hydrauliczne na fizycznych modelach cieków, budowli lub konstrukcji wodnych. Działają one okresowo w czasie prowadzenia badań, zapewniają uzyskanie pomiarów o małej niepewności i współdziałają ze stałymi systemami badawczymi. Są one wykorzystywane według ustalonych procedur badawczych, umożliwiających gromadzenie, transmisję i weryfikację wyników (Bajkowski, 2009). Przelewy te są dowolnie konfigurowane na stanowiskach badawczych i zazwyczaj mierzą przepływ wody czystej.

Przelewy terenowe dzielą się na pomiarowe oraz budowlane. Terenowe przelewy pomiarowe przeznaczone są do pomiaru ilości cieczy przepływającej w technologicznych systemach przemysłowych, na ujęciach wodnych, na wlotach i wylotach oczyszczalni ścieków oraz na stacjach monitoringu ilościowego wód, w przekrojach hydrometrycznych służby hydrologicznej. Najliczniejszą grupę stanowią przelewy budowlane, stanowiące stałe progi lub ruchome zamknięcia budowli hydrotechnicznych, ponad którymi przelewa się woda. Ich głównym zadaniem jest utrzymanie piętrzenia $\mathrm{w}$ zbiorniku. Jednocześnie spełniają one funkcje regulatorów przepływu i poziomu wody oraz są wykorzystywane do pomiaru ilości wody przepływającej przez przekrój piętrzenia.

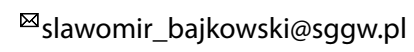


Wydatek oraz formy przepływu na przelewach zależą od ich geometrii oraz konstrukcji stanowiska górnego i dolnego. W obliczeniach przepustowości przelewów uwzględnia się oddziaływanie ograniczeń konstrukcyjnych, do których należą (Bajkowski, 2016):

- ograniczenia denne charakteryzowane kształtem i wysokością progu przelewowego,

- ograniczenia boczne tworzące częściowe lub pełne dławienie boczne,

- kształt przekroju poprzecznego progu,

- rodzaj i stan powierzchni konstrukcji progu przelewowego.

Historyczne badania kształtu strumienia przelewów o szerokiej koronie opisali Rouse, red. (1967) i Tracy, red. (1957). Do wyników tych odnosi się większość późniejszych badań zarówno dotyczących określenia wartości współczynnika wydatku (Clemmens, Replogle i Reinink, 1990; Salmasi, Poorescandar, Dalir i Zadeh, 2011; Hoseini i Afshar, 2014; Bajkowski, 2016), jak i układu zwierciadła wody (Leu, Chan i Chu, 2008; Goodarzi, Farhoudi i Shokri, 2012). Najnowsze badania układu strumienia przelewów o różnych kształtach przekroju poprzecznego, prostoliniowych i rozwiniętych w planie opisał Emiroglu (2010). Kształt dolnej strugi obrysu strumienia przelewowego powyżej krawędzi o ostrym kształcie opisali Bagheri i Heidarpur (2010), a ciśnienia na koronie przelewu - Moñino, Losada i Riera (2007) oraz Reese i Maynord (1987). Podsumowaniem badań kształtu obrysu strumienia przelewowego przelewów o ostrej krawędzi jest opis podany przez Hagera i Boesa (2015). Z rozpoznania parametrów hydraulicznych strumienia na progach przelewów o szerokości korony przekraczającej 2,5 $H$ (gdzie $H$ jest wzniesieniem zwierciadła wody górnej nad koroną przelewu) wynika, że występuje na nich zróżnicowany kształt profilu zwierciadła wody (Goodarzi i in., 2012; Kim, Choi, Park i Byeon, 2015). Kształt ten zależny jest od stosunku $L / H$ (gdzie $L$ jest szerokością korony progu przelewowego), co w swojej pracy opisał Bajkowski (2013).

$\mathrm{W}$ artykule przedstawiono wykorzystywanie laboratoryjnych badań fizycznych oraz symulacji numerycznych do analizy kształtu strumienia przelewowego na progach przelewów o szerokiej koronie. Te dwa obszary badawcze coraz częściej są łączone w rozpoznaniu przepływu przez budowle wodne (Książek, Strużyński, Leja i Pilch, 2011; Grobelny, Kubicz i Tymiński, 2014; Kałuża, Zawadzki i Jaszczak, 2014). Do badań wybrano przelew o prostokątnym przekroju otworu przelewowego oraz trapezowym asymetrycznym kształcie progu. Układ swobodnego zwierciadła wody ustalono według badań laboratoryjnych oraz obliczeń numerycznych w środowisku ANSYS-Fluent (ANSYS Fluent Release 12.1., 2009). Artykuł zawiera graficzne zastawienia profili swobodnego zwierciadła wody uzyskane $z$ badań i obliczeń oraz wartości statystyk wykorzystywanych $\mathrm{w}$ ocenie ich zgodności. Dla analizowanych warunków uzyskano bardzo dobrą zgodność współrzędnych obliczonego i pomierzonego zwierciadła wody na badanym przelewie.

\section{MATERIA I METODY}

\section{Badania laboratoryjne}

Badania laboratoryjne przeprowadzono na modelu trapezowego przelewu o pionowej ścianie górnej i płaszczyźnie spływowej nachylonej w stosunku 1:1. Model wbudowano w koryto obustronnie oszklone szerokości $0,203 \mathrm{~m}$, wysokości $0,40 \mathrm{~m}$ i długości 4,0 $\mathrm{m}$. Na rysunku 1 pokazano kształt badanego modelu oraz podstawowe wielkości charakteryzujące układ swobodnego zwierciadła wody. W badaniach wykorzystano aparaturę i procedury badawcze opisane przez Bajkowskiego $(2009,2010,2015)$. Parametry geometryczne modelu oraz zakresy pomiarowe mierzonych wielkości zestawiono w tabeli 1.

Wartości liczby Reynoldsa podane w tabeli 1 obliczono z następującego wzoru:

$$
\operatorname{Re}=\frac{\sqrt{2 \mathrm{~g} H_{\mathrm{o}}} \cdot H_{\mathrm{o}}}{v}
$$

gdzie: $H_{\mathrm{o}}-$ wzniesienie linii energii wody górnej nad koroną przelewu [m]

$$
H_{o}=H+\frac{V_{\mathrm{g}}^{2}}{2 \mathrm{~g}}
$$

$V_{g}-$ prędkość dopływającej wody $\left[\mathrm{m} \cdot \mathrm{s}^{-1}\right]$ :

$$
V_{\mathrm{g}}=\frac{Q}{B(H+P)}
$$

$v$ - kinematyczny współczynnik lepkości wody $\left(v_{20}=1,01 \cdot 10^{-6} \mathrm{~m}^{2} \cdot \mathrm{s}^{-1}\right)$,

$\mathrm{g}$ - przyspieszenie ziemskie $\left(\mathrm{g}=9,81 \mathrm{~m} \cdot \mathrm{s}^{-2}\right)$. 


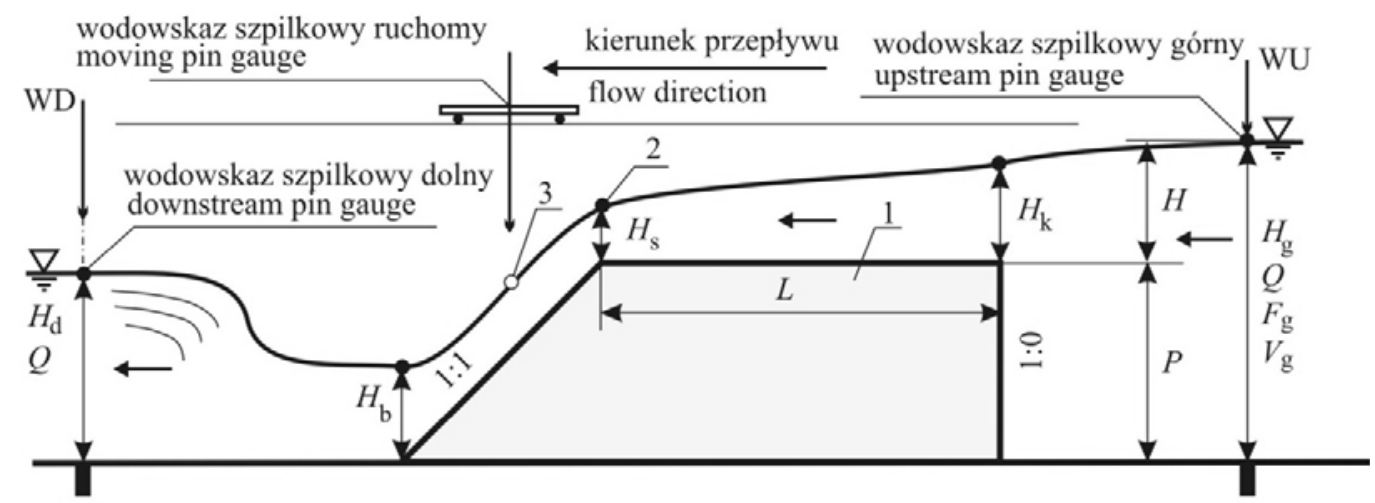

Rys. 1. Schemat przelewu badawczego: $Q$ - natężenie przepływu, $V_{g}$ - prędkość dopływającej wody, $F_{g}$ - powierzchnia przekroju strumienia dopływającego, $H_{g}, H, H_{k}, H_{s}, H_{b}, H_{d}$ - głębokości strumienia, $L$ - szerokość korony przelewu, $P$-wysokość progu przelewu; 1 - próg przelewu, 2 - stałe punkty pomiarowe, 3 -zmienne punkty pomiarowe

Fig. 1. Scheme of the tested weir: $Q$ - flow discharge, $V_{g}$ - approach flow velocity, $F_{g}$ - approach stream section area, $H_{g}$, $H, H_{k}, H_{s}, H_{b}, H_{d}$ - stream depths, $L$ - long of the weir crest, $P$ - height of the weir crest; 1 - weir sill, 2 - constant measuring points, 3 - movable measuring points

Tabela 1. Parametry modelu fizycznego i zakresy wielkości pomiarowych

Table 1. Parameters of the physical model and values measuring ranges

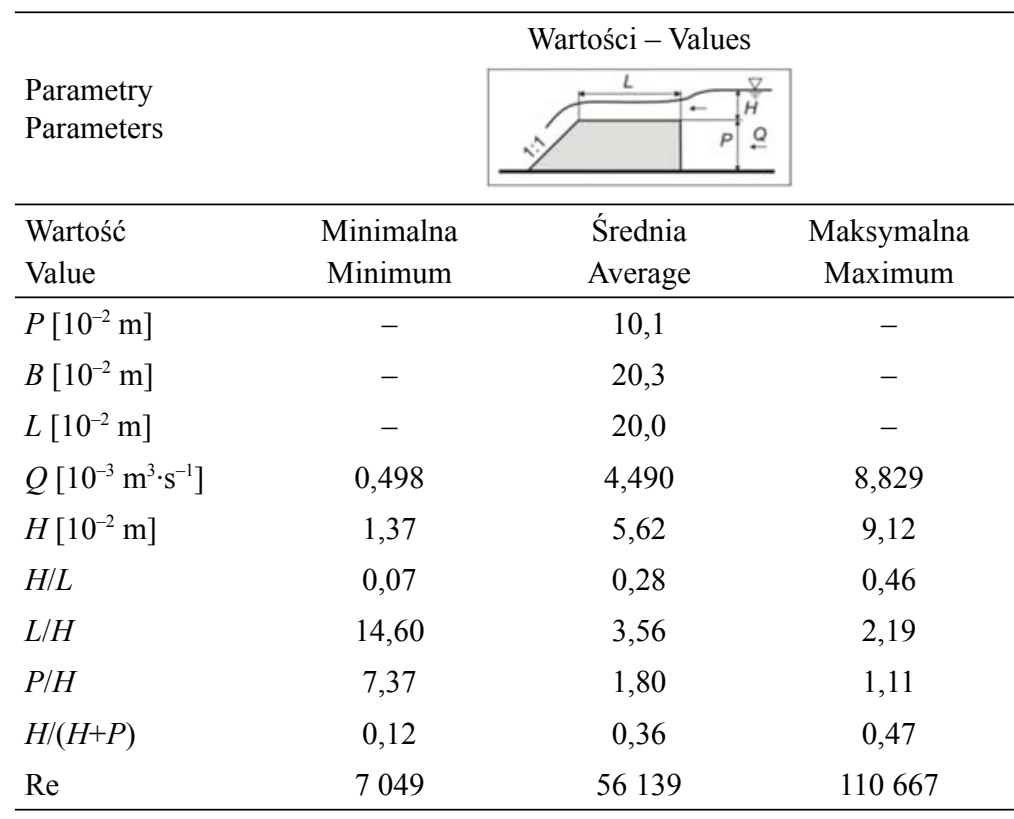

Krzywą przepustowości modelu przelewu pokazano na rysunku 2. Na krzywej oznaczono pomiary, dla których wykonano obliczenia numeryczne przepływu oraz przeprowadzono analizy profilu swobodnego zwierciadła wody.
Na rysunku 3 przedstawiono układy zwierciadła wody pomierzone na modelu dla wskazanych pomiarów. Profile zwierciadła wody pokazano na tle fotografii dla pomiaru Pom4, obrazującej układ linii prądu wyznaczonych wprowadzonym w strumień barwnikiem. 


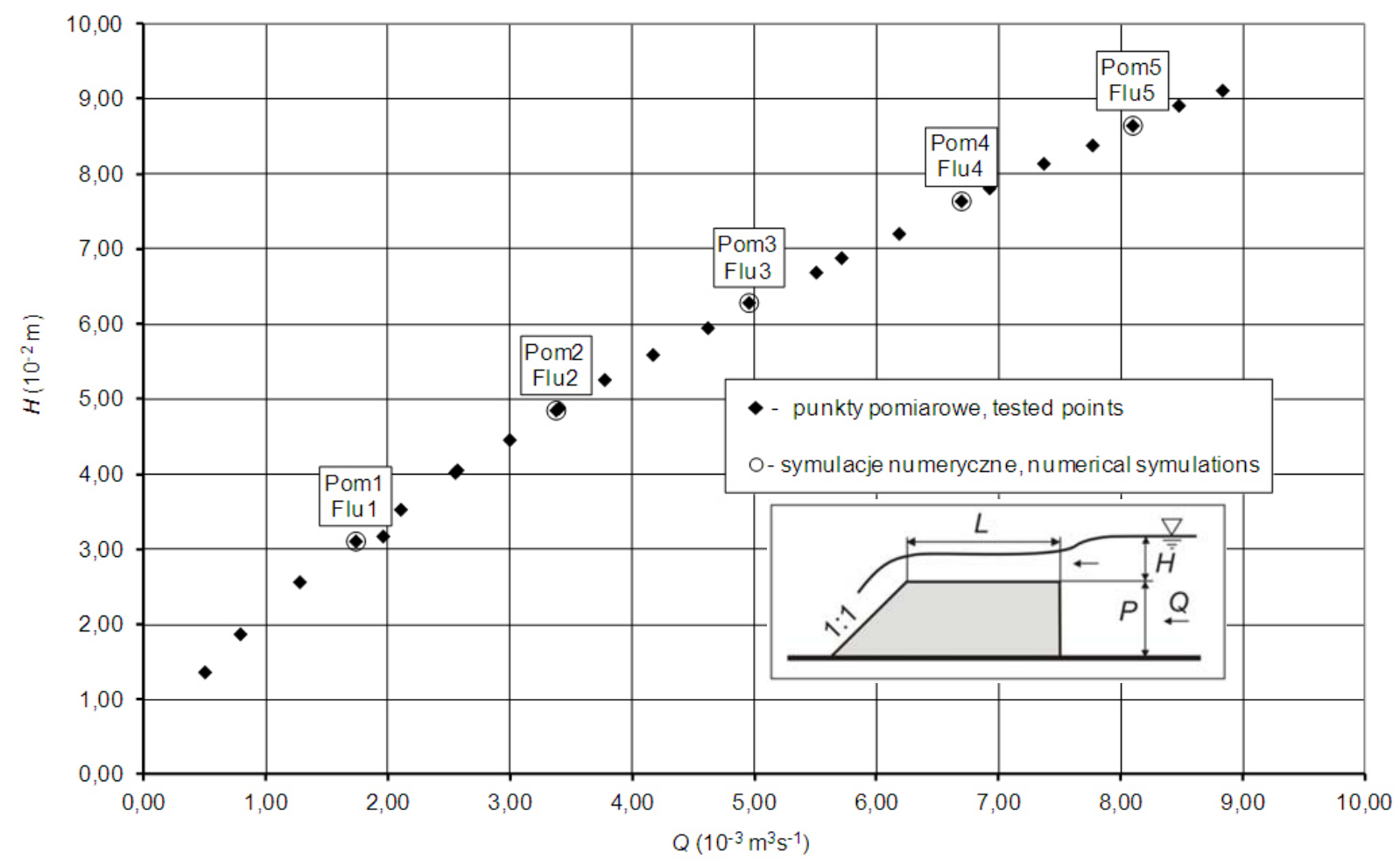

Rys. 2. Krzywa przepustowości badanego przelewu

Fig. 2. Discharge curve of tested weir

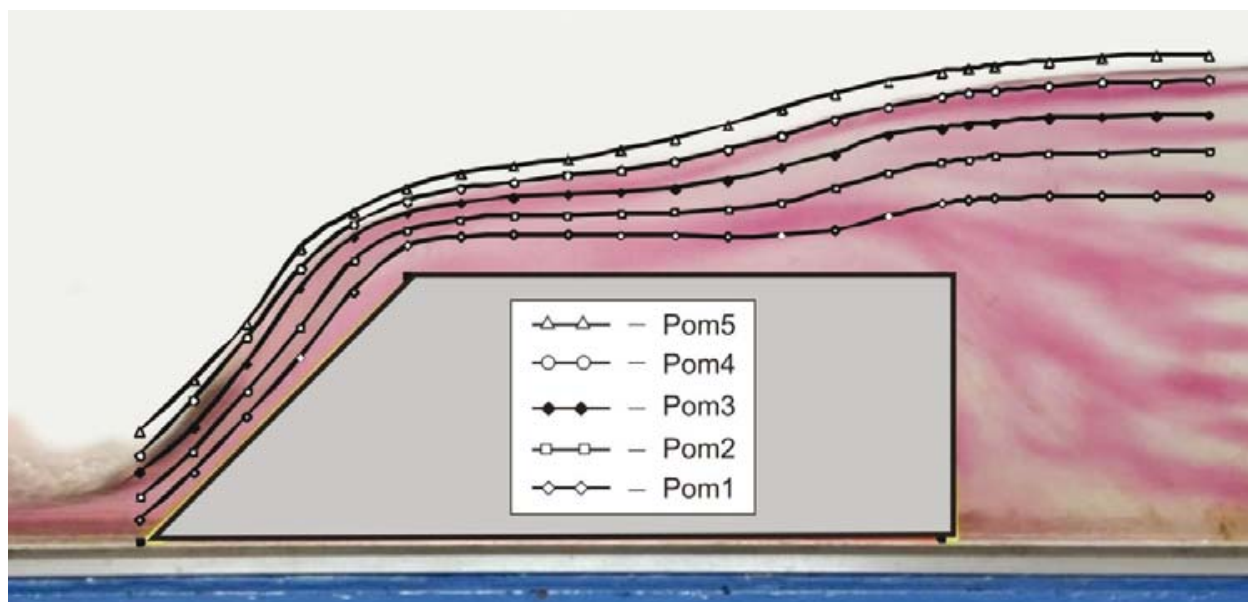

Rys. 3. Pomierzone profile swobodnego zwierciadła wody

Fig. 3. Measured free water surface profiles

Występujące zaburzenia przepływu zobrazowane mieszaniem się barwnika wskazują na wzrost turbulencji strumienia nad progiem. Znaczący wzrost prędkości wystapił na powierzchni spływowej przelewu, co opi- sali też Hager i Schwalt (1994) oraz Leu i inni (2008). Wzrostowi temu towarzyszy zmniejszanie się głębokości wody na długości dolnej skarpy progu przelewowego (Maghrebi, Alizadeh i Lotfi, 2012). 


\section{Obliczenia numeryczne}

Do analiz numerycznych przepływu na modelu symulacyjnym wykorzystano obliczeniową mechanikę płynów CFD (Computational Fluid Dynamics), a obliczenia wykonano w środowisku programowania ANSYS-Fluent Release 12.1. W modelowaniu swobodnego zwierciadła wody przy przepływie przez próg przelewu zastosowano metodę VOF (Volume of Fluid) oraz model przepływu turbulentnego $k-\varepsilon$ standard, który wykorzystuje się w obliczeniach symulacyjnych w zakresie wysokich liczb Reynoldsa (Mohammadpour, Ghani i Azamathulla, 2013). W metodzie VOF równania transportu rozwiązywane są oddzielnie dla każdej z faz (w rozpatrywanym przypadku fazami są woda i powietrze), jak również dla całej objętości i wyznaczany jest stosunek objętości fazy wody do fazy powietrza (Volume Fraction). Wielkość ta przyjmuje wartość od 0 do 1 dla obu faz. Swobodne zwierciadło wody wykorzystywane $\mathrm{w}$ analizach porównawczych przyjęto na poziomie 0,5 tego stosunku, jak podali Haun, Reidar, Olsen i Feuch (2011).
Do szczegółowych analiz numerycznych wybrano 5 pomiarów (Flu1, Flu2, Flu3, Flu4, Flu5). Dane wejściowe do modelu numerycznego zestawiono $\mathrm{w}$ tabeli 2 , a schemat wykorzystany $\mathrm{w}$ obliczeniach numerycznych przestawiono na rysunku 4 . Symulacje przeprowadzono dla przekroju wlotowego typu pole prędkości (velocity - inlet) o stałej prędkości $\left(V_{w}\right)$ na całej wysokości $\left(H_{w}\right)$ przekroju wlotowego. Wartości $V_{\mathrm{w}}$ określono według pomiarów laboratoryjnych. W przekroju wylotowym założono schemat ciśnieniowy (pressure - outlet), wprowadzając pomierzone na modelu wartości głębokości wody $\left(H_{d}\right)$. Szorstkość bezwzględną powierzchni ścian i dna koryta badawczego zdefiniowano jako $k_{1}$, a progu jako $k_{2}$. Wartości szorstkości bezwzględnych $k_{1}$ oraz $k_{2}$ dobrano, kierując się rodzajem i stanem powierzchni oraz wynikami analiz opisanych przez Bajkowskiego (2013).

Obliczone profile swobodnego zwierciadła wody dla przepływów wytypowanych do analiz przedstawiono na rysunku 5. Opracowano je na tle wyników pomiaru Flu4, dla którego dołączono wykresy rozkładów prędkości w obszarze zawartości fazy ciekłej.

Tabela 2. Parametry wejściowe modelu numerycznego

Table 2. Input parameters of the numerical model

\begin{tabular}{|c|c|c|c|c|c|}
\hline \multirow{4}{*}{$\begin{array}{l}\text { Parametry } \\
\text { Parameters }\end{array}$} & \multicolumn{5}{|c|}{ Wartości - Values } \\
\hline & & & $L$ & & \\
\hline & & & & & \\
\hline & Flu1 & Flu2 & Flu3 & Flu4 & Flu5 \\
\hline$Q\left[10^{-3} \mathrm{~m}^{3} \cdot \mathrm{s}^{-1}\right]$ & 1,733 & 3,372 & 4,952 & 6,691 & 8,093 \\
\hline$H_{d}\left[10^{-2} \mathrm{~m}\right]$ & 0,046 & 0,067 & 0,083 & 0,097 & 0,108 \\
\hline$H_{g}\left[10^{-2} \mathrm{~m}\right]$ & 0,133 & 0,150 & 0,164 & 0,178 & 0,188 \\
\hline$F_{g}\left[\mathrm{~m}^{2}\right]$ & 0,0270 & 0,0305 & 0,0333 & 0,0361 & 0,0381 \\
\hline$V_{g}\left[\mathrm{~m} \cdot \mathrm{s}^{-1}\right]$ & 0,064 & 0,111 & 0,149 & 0,185 & 0,212 \\
\hline$H_{w}\left[10^{-2} \mathrm{~m}\right]$ & 0,306 & 0,306 & 0,306 & 0,306 & 0,306 \\
\hline$F_{w}\left[\mathrm{~m}^{2}\right]$ & 0,0622 & 0,0622 & 0,0622 & 0,0622 & 0,0622 \\
\hline$V_{w}\left[\mathrm{~m} \cdot \mathrm{s}^{-1}\right]$ & 0,028 & 0,054 & 0,080 & 0,108 & 0,130 \\
\hline$k_{1}[\mathrm{~m}]$ & $1,0 \mathrm{e}-04$ & $1,0 \mathrm{e}-04$ & $1,0 \mathrm{e}-04$ & $1,0 \mathrm{e}-04$ & $1,0 \mathrm{e}-04$ \\
\hline$k_{2}[\mathrm{~m}]$ & $5,0 \mathrm{e}-05$ & $5,0 \mathrm{e}-05$ & $5,0 \mathrm{e}-05$ & $5,0 \mathrm{e}-05$ & $5,0 \mathrm{e}-05$ \\
\hline
\end{tabular}




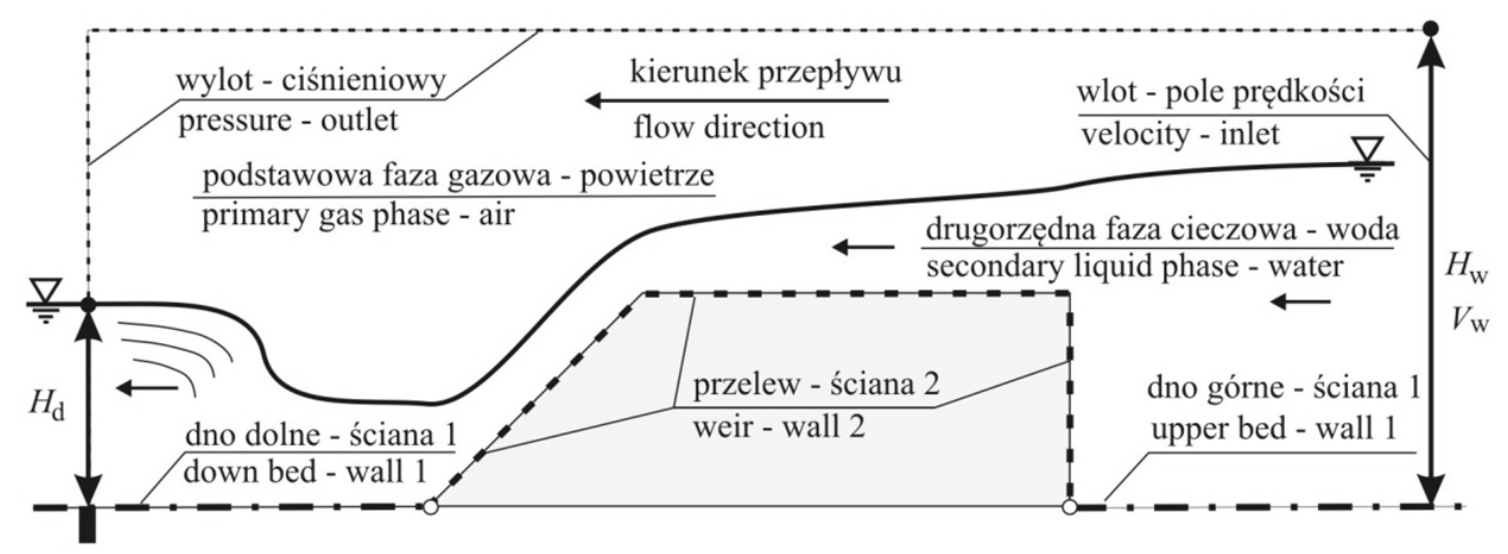

Rys. 4. Schemat przelewu obliczeniowego: $H_{w}, H_{d}-$ głębokości strumienia na wlocie i wylocie, $V_{w}$-prędkość przepływu na wlocie

Fig. 4. Scheme of the calculated weir: $H_{w}, H_{d}$ - inlet and outlet stream depths, $V_{w}$ - inlet flow velocity

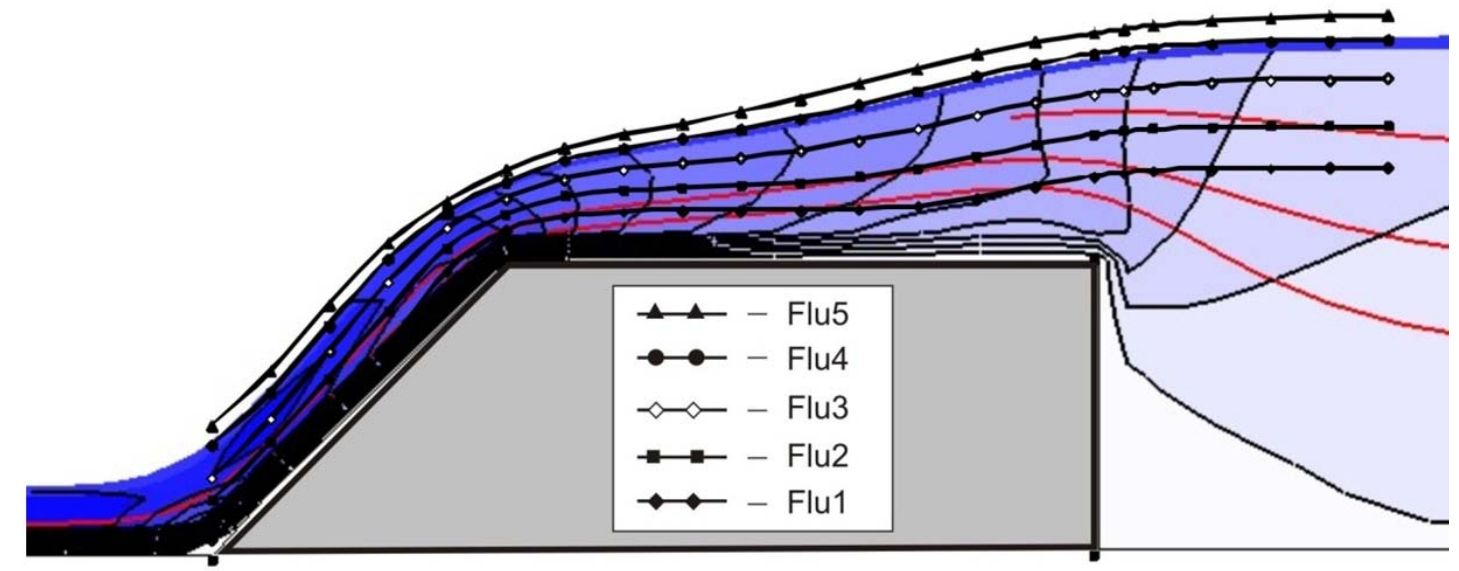

Rys. 5. Obliczone układy swobodnego zwierciadła wody

Fig. 5. Calculated free water surface profiles

Uzyskane rozkłady odzwierciedlają zwiększanie się prędkości przepływu nad krawędzią przelewu (Zachoval, 2015) oraz jej znaczący wzrost na długości powierzchni spływowej przelewu.

\section{WYNIKI}

Badania laboratoryjne uzupełniono symulacjami numerycznymi przepływu wykonanymi dla przelewu o takiej samej konstrukcji i identycznych warunkach przepływu. W celu zobrazowania podobieństw układów pomierzonego i symulacyjnego wyniki obliczeń odniesiono do tych samych przekrojów. Profile swobodnego zwierciadła wody pomierzony i obliczony dla pomiaru Pom3 - Flu3 $\left(Q=6,691 \cdot 10^{-3} \mathrm{~m}^{3} \cdot \mathrm{s}^{-1}\right.$, $\left.V_{w}=0,080 \mathrm{~m} \cdot \mathrm{s}^{-1}, H_{d}=0,083 \cdot 10^{-2} \mathrm{~m}\right)$ przedstawiono na rysunku 6 . Wykonano je dla niezatopionego strumienia, w obszarze wody górnej, na szerokości korony przelewu oraz na długości dolnej skarpy. Widoczne są różnice rzędnych w układzie na długości korony przelewu; powyżej przelewu i na długości skarpy dolnej przebieg profili jest zgodny.

Do zdefiniowania typu zgodności obu profili wykorzystano analizę statystyczną ciagów zdarzeń cech pomierzonych oraz obliczonych. Analizy prowadzono dla jednorodnych warunków, odnosząc pary cech 


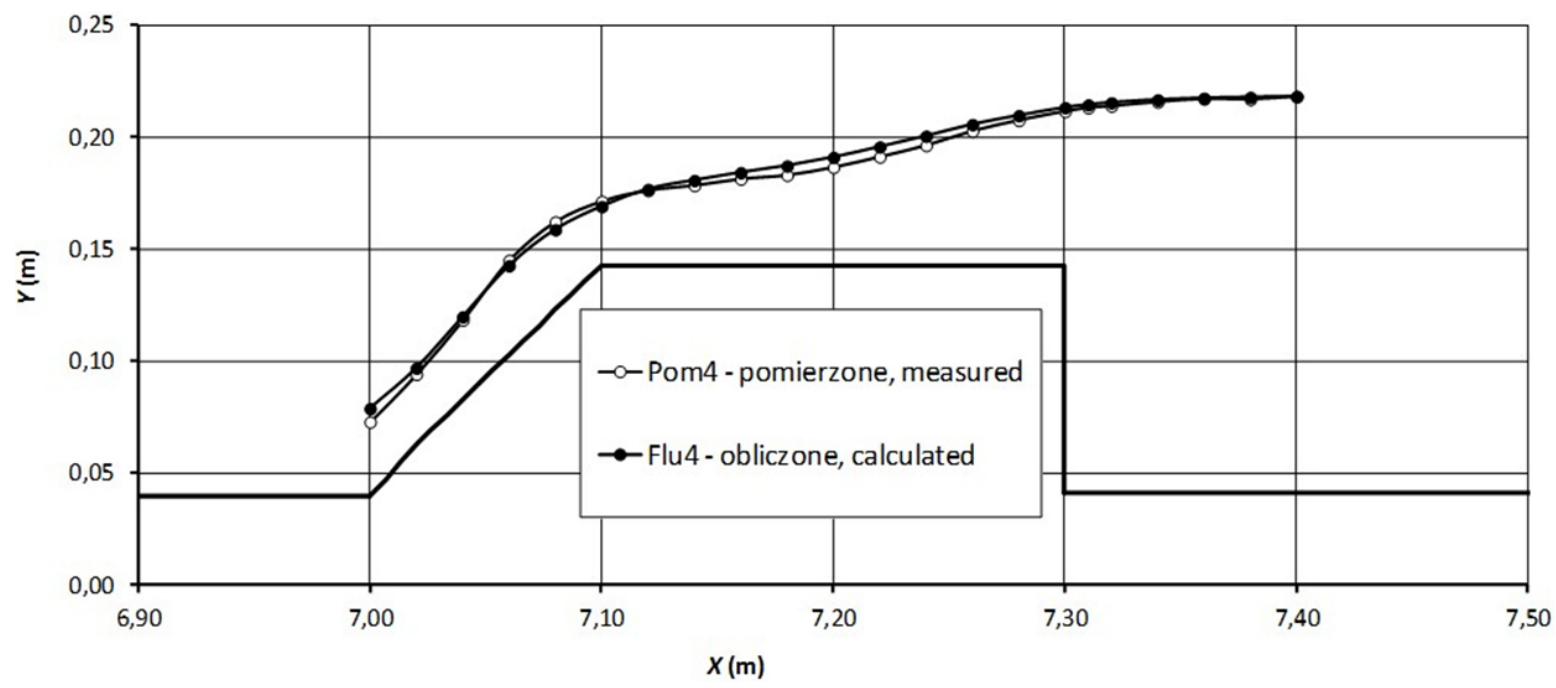

Rys. 6. Porównanie układów swobodnego zwierciadła wody $\left(Q=6,691 \cdot 10^{-3} \mathrm{~m}^{3} \cdot \mathrm{s}^{-1}\right)$

Fig. 6. Comparison free water surface profiles $\left(Q=6,691 \cdot 10^{-3} \mathrm{~m}^{3} \cdot \mathrm{s}^{-1}\right)$

do tych samych przekrojów. Graficzne przestawienie rzędnych profilu obliczonego i pomierzonego, pokazane na rysunku 7, wskazuje na dużą ich zgodność. Stopień zgodności wyników uzyskanych z obliczeń numerycznych i pomiarów ustalano, wykorzystując statystyki do oceny siły związku wielkości pomierzonej i obliczonej przy jednakowej liczebności elementów próbek badanej cechy. Do oceny wykorzystano

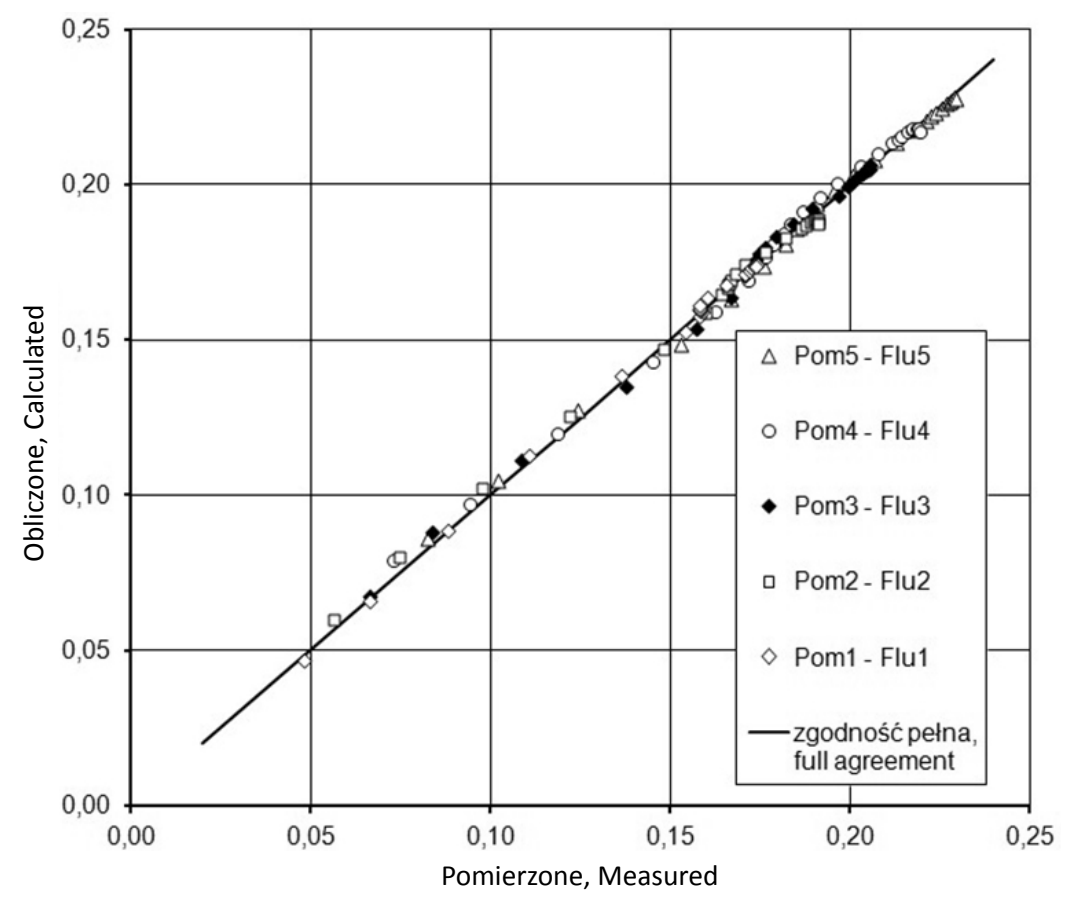

Rys. 7. Pomierzone i obliczone punkty swobodnego zwierciadła wody nad badanym przelewem

Fig. 7. Measured and calculated points of free surface profiles above tested weir 
Tabela 3. Statystyki dopasowania układu swobodnego zwierciadła wody z pomiarów (Pom) i obliczeń (Flu)

Table 3. Statistics compliance water free surface profile from measurement (Pom) and calculation (Flu)

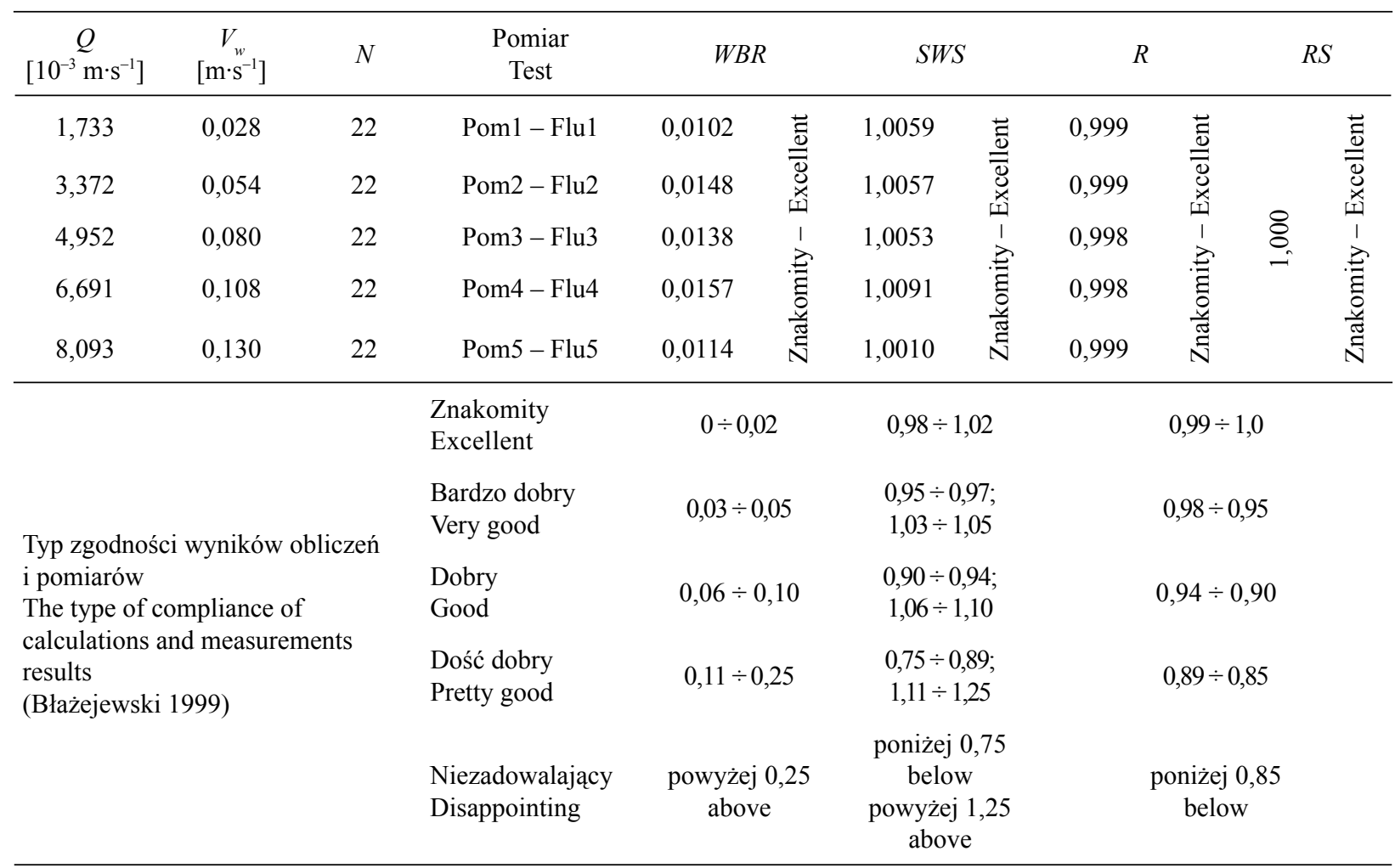

miary statystyczne i klasy stopnia dopasowania modelu podane przez Błażejewskiego (1999):

- WBR - względny średniokwadratowy błąd resztowy,

- SWS - stosunek wartości średnich,

- $R$ - współczynnik korelacji,

- $R S$ - specjalny współczynnik korelacji.

Wartości zebranych miar statystycznych wskazuja na znakomitą korelację pomiędzy obliczonymi i pomierzonymi rzędnymi swobodnego zwierciadła wody (tab. 3).

\section{PODSUMOWANIE}

Badania laboratoryjne stanowią dobrą podstawę do oceny wyników obliczeń numerycznych. Utrzymanie ustalonych warunków przepływu oraz wykorzystanie laboratoryjnych urządzeń pomiarowych pozwala uzyskać dokładne i precyzyjne wartości współrzędnych swobodnego zwierciadła wody. Wykorzystując metodę obliczeniową VOF, można wyznaczyć współrzędne układu swobodnego zwierciadła wody na przelewach, o dużej zgodności z wynikami uzyskanymi z testów laboratoryjnych. Obliczenia numeryczne umożliwiają też ustalenie rozkładów prędkości w strumieniu, a w warunkach laboratoryjnych punktowe pomiary prędkości należą do najbardziej czasochłonnych. Zgodność dopasowania profilu swobodnego zwierciadła wody oszacowano, wykorzystując statystyki określone dla ciagów utworzonych z par wartości rzędnych zwierciadła wody dla modelu laboratoryjnego i obliczeniowego. Wyznaczenie wartości rzędnych w tych samych przekrojach zapewniało jednorodność analizowanych ciagów par. Profile zwierciadła wody pomierzone $\mathrm{w}$ warunkach laboratoryjnych i uzyskane z obliczeń numerycznych dla badanego modelu i warunków hydraulicznych cechuje znakomita zgodność na całej długości analizowanego przelewu. 


\section{PIŚMIENNICTWO}

ANSYS Fluent Release 12.1. (2009). Workbench Guide, Modeling and Meshing Guide, Theory Guide. ANSYS, Inc. Documentation for Release 12.1.

Bagheri, S. i Heidarpour, M. (2010). Flow over rectangular sharp-crested weirs. Irrigation Science, 28, 173-179. doi: 10.1007/s00271-009-0172-1

Bajkowski, S. (2009). System pomiarowo-kontrolny Laboratorium Hydraulicznego SGGW. W A. Wita, Monografie IMGW. Bezpieczeństwo zapór - bezpieczeństwo ludności i środowiska (strony 195-203). Warszawa: Instytut Meteorologii i Gospodarki Wodnej.

Bajkowski, S. (2010). Współczesne techniki pomiarowe laboratoriów wodnych. Infrastruktura i Ekologia Terenów Wiejskich, 8 (2), 37-50.

Bajkowski, S. (2013). Warunki przeptywu wody przez budowle przepuszczalne. Rozprawy Naukowe i Monografie, 431. Warszawa: Wydawnictwo SGGW.

Bajkowski, S. (2015). Współczynnik zatopienia progu przepuszczalnego. Acta Scientiarum Polonorum Architectu$\mathrm{ra}, 14(2), 53-62$.

Bajkowski, S. (2016). Współczynnik wydatku przelewów gładkich o szerokiej koronie. Wiadomości Melioracyjne i Łakarskie, 2, 59-64.

Błażejewski, R. (1999). Wstęp do badań empirycznych. Poznań: Wydawnictwo Akademii Rolniczej im. Augusta Cieszkowskiego.

Clemmens, A. J., Replogle, J. A. i Reinink, Y. (1990). Field predictability of flume and weir operating conditions. Journal of Hydraulic Engineering, 116 (1), 102-118.

Emiroglu, M. E. (2010). Estimating flow characteristics of different weir types and optimum dimensions of downstream receiving pool. Journal of Hydrology and Hydromechanics, 58(4), 245-260. doi: 10.2478/v10098$-010-0023-\mathrm{z}$

Goodarzi, E., Farhoudi, J. i Shokri, N. (2012). Flow characteristics of rectangular broad-crested weirs with sloped upstream face. Journal of Hydrology and Hydromechanics, 60 (2), 87-100. doi: 10.2478/v10098-012-0008-1

Grobelny, M., Kubicz, J. i Tymiński, T. (2014). Zastosowanie CCHE2D do modelowania warunków hydrodynamicznych małego cieku. Zeszyty Naukowe - Inżynieria Ladowa $i$ Wodna $w$ Ksztaltowaniu Środowiska, 11 30-37.

Hager, W. H. i Boes, R. M. (2015). Spillway jet: Historical advance from weir toward standard spillway. In E-Proceedings of the 36th International Association for Hydro-Environment Engineering and Research
World Congress (pages 1-8) 28 June - 3 July, The Hague, The Netherlands.

Hager, W. H. i Schwalt, M. (1994). Broad-crested weir. Journal of Irrigation and Drainage Engineering, 120 (1), 13-25.

Haun, S., Reidar, N., Olsen, B. i Feurich, R. (2011). Numerical modeling of flow over trapezoidal broad-crested weir. Engineering Applications of Computational Fluid Mechanics, 5 (3), 397-405.

Hoseini, S. H. i Afshar, H. (2014). Flow over a broad-crested weir in subcritical flow conditions, Physical Study. Journal of River Engineering, 2 (1), 1-6.

Kałuża, T., Zawadzki, P. i Jaszczak, G. (2014). Efekt skalowy w laboratoryjnych badaniach hydraulicznych na przykładzie hydrantu o dużej wydajności. Aparatura Badawcza i Dydaktyczna, 2, 141-146.

Kim, Y., Choi, G., Park, H. i Byeon, S. (2015). Hydraulic jump and energy dissipation with sluice gate. Water, 7 , 5115-5133. doi: 10.3390/w7095115

Książek, L., Strużyński, A., Leja, M. i Pilch, E. (2011). Modelowanie fizyczne i numeryczne przepływu wody w przepławce biologicznej. Acta Scientiarum Polonorum Formatio Circumiectus, 10 (4), 17-30.

Leu, J. M., Chan, H. C. i Chu, M. S. (2008). Comparison of turbulent flow over solid and porous structures mounted on the bottom of a rectangular channel. Flow Measurement and Instrumentation, 19, 331-337. doi: 10.1016/ j.flowmeasinst.2008.05.001

Maghrebi, M., Alizadeh, S. i Lotfi, R. (2012). Numerical simulation of flow over rectangular broad crested weir (Real case study). In The First International Conference on Dams and Hydropower (pages 1-7).

Mohammadpour, R., Ghani, A. A. i Azamathulla, H. M. (2013). Numerical modeling of 3-D flow on porous broad crested weirs. Applied Mathematical Modelling, 22 (37), 9324-9337.

Moñino, A., Losada, M. A. i Riera, J. (2007). Steady flow regime for free overfall spillways. Influence of the ascending branch of the spillway crest. Journal of Hydraulic Research, 45 (3), 388-399.

Reese, A. J. i Maynord, S. T. (1987). Design of spillway crests. Journal of Hydraulic Engineering, 113(4), 476-490.

Rouse, H. (red.) (1967). Engineering Hydraulics. New York - London - Sydney: John Wiley \& Sons.

Salmasi, F., Poorescandar, S., Dalir, A. H. i Zadeh, D. F. (2011). Discharge relations for rectangular broad-crested weirs. Journal of Agricultural Sciences, 17, 324 -336 .

Tracy, H. J. (red.). (1957). Discharge characteristics of broad-crested weirs. Geological Survey Circular, 397. Washington: United States Department of the Interior. 
Zachoval, Z. (2015). Broad-crested weirs with rectangular control section. Vysoké Učení Technické v Brně. Fakulta stavební. Ústav vodních staveb. Vědecké Spisy
Vysokého Učeni Tecoického v Brně. Vodní hospodářství a vodní stavby. Edice Habilitačni a inauguračai spisy, 494. Brno: Vutium.

\section{TRAPEZOIDAL WEIR WITH VERTICAL UPSTREAM FACE}

\section{ABSTRACT}

In the article described the use of laboratory tests and modern computational techniques to determine the shape of the free water profile over the sill a long crested weir. The analysis of the trapezoidal weir with a vertical upstream face and down surface slanted in a 1:1 ratio were performed. Physical model tests were performed in a laboratory channel width of $0.20 \mathrm{~m}$ and length of $4.0 \mathrm{~m}$. Computer simulations using the VOF method used in CFD fluid mechanics computing techniques using the ANSYS-Fluent programming environment were conducted. The coordinates of the water profile obtained from numerical simulations are compared to the measured values. This is confirmed by statistical analyzes that showed excellent correlation between computational and measurement coordinates.

Key words: broad-crested weir, free water surface profile, laboratory tests, numerical calculations 